\section{'Gem' Pear}

\author{
Richard L. Bell ${ }^{1,3}$ and Tom van der Zwet ${ }^{2}$ \\ U.S. Department of Agriculture, Agricultural Research Service, Appalachian \\ Fruit Research Station, 2217 Wiltshire Road, Kearneysville, WV 25430
}

\begin{abstract}
Steve Castagnoli, Todd Einhorn, Janet D. Turner, and Robert Spotts
Oregon State University, Mid-Columbia Agricultural Research and Extension Center, 3005 Experiment Station Drive, Hood River, OR 97031
\end{abstract}

\author{
Gary A. Moulton \\ Washington State University, Mount Vernon Northwestern Washington \\ Research Center, 16650 State Road 536, Mount Vernon, WA 98273
}

\section{Greg L. Reighard}

Clemson University, Department of Horticulture, 170 Poole Agricultural Center, Clemson, SC 29634

\section{William W. Shane \\ Michigan State University, Southwest Michigan Research and Extension Center, 1791 Hillandale Road, Benton Harbor, MI 49022}

Additional key words. breeding, cultivar, fruit quality, precocity, productivity, Pyrus communis, storage life

'Gem' is a new cultivar that combines excellent appearance, fruit quality, and long storage potential with precocious and high yields. It can be eaten without ripening as a result of a crisp, juicy texture as well as ripened to a soft texture. 'Gem' was jointly released by the U.S. Department of Agriculture, Oregon State University, Michigan State University, and Clemson University in 2013.

\section{Origin}

The cross from which 'Gem' was selected, 'Sheldon' $\times$ US62563-004 (Fig. 1), was

\footnotetext{
Received for publication 21 Oct. 2013. Accepted for publication 27 Dec. 2013.

We thank Roland C. Blake, former Research Horticulturist with the USDA, ARS stationed at the Ohio Agricultural Research and Development Center, Wooster, $\mathrm{OH}$, for cooperation in planning the cross. We also recognize the technical contributions of Mr. Wayne Zook and Mr. Greg Brenneman. We thank additional James Nugent of Michigan State University, Northwest Michigan Horticulture Research Station, for conducting evaluations of production and fruit quality. We also thank Dr. Kenneth Eastwell and Mr. William Howell of the National Clean Plant Network-Fruit Trees, Clean Plant Center of the Northwest at Washington State University, Irrigated Agriculture Research and Extension Center, for providing virus and phytoplasma testing.

Mention of trade names or commercial products in this publication is solely for the purpose of providing specific information and does not imply recommendation or endorsement by the U.S. Department of Agriculture. USDA is an equal opportunity provider and employer.

${ }^{1}$ Research Horticulturist.

${ }^{2}$ Research Plant Pathologist, retired.

${ }^{3}$ To whom reprint requests should be addressed; e-mail richard.bell@ars.usda.gov.
}

1983). Fruit from unthinned trees at AFRS were moderate in size with fruit length and width averaging $76.5 \mathrm{~mm}$ and $70.9 \mathrm{~mm}$, respectively. The stems are of uniform diameter or rarely slightly clubbed at the base, upright or occasionally oblique, averaging $29.2 \mathrm{~mm}$ in length and $3.4 \mathrm{~mm}$ in diameter (Table 1). The cavity is acute and 1 to $2 \mathrm{~mm}$ in depth; the basin is wide (17 to $25 \mathrm{~mm}$ ) and shallow (2 to $6 \mathrm{~mm}$ ). The calyx is convergent and the tube is urn-shaped. The undercolor is yellow-green, predominantly 114A of the Royal Horticultural Society (RHS) Color Chart (Fourth Edition, RHS, London, U.K.), and the sun-exposed side of fruit are frequently covered with orange-red (34A or $34 \mathrm{~B})$ or red (42A) blush. At AFRS, the percentage of fruit surface covered by blush averaged $20 \%$ (Table 1); in the high-light environment of Hood River, fruit exposed to sunlight developed red to orange-red pigmentation over $25 \%$ to $50 \%$ of the surface. The skin is smooth and waxy with a glossy finish with some tendency to marking as a result of abrasion. Skin is moderate in thickness with no bitterness or astringency. Russet was small and sparse at AFRS, primarily appearing as prominent lenticel russet, appearing as only small lenticel russet at Mount Vernon, and absent at MCAREC. Lenticels are round, conspicuous but small, dark tan in color, and of moderate density (Table 1). Overall appearance scores were similar to 'Bartlett' and 'Beurré Anjou'.

The flesh is creamy white in color. Mean core diameter is $16 \mathrm{~mm}$, and the cells are closed. The carpels are mucronate, and the seed is acuminate in shape. Grit content is light and less than 'Bartlett' and 'Beurré Anjou'; grit size was small, of uniform size distribution, and located primarily in the flesh and under the skin with little prominent grit around the core.

At AFRS, optimum maturity was estimated at 17 to $30 \mathrm{~d}$ after 'Bartlett'. At AFRS the mean maturity date for 'Gem' was 8 Sept., whereas mean 'Bartlett' maturity occurred on 18 Aug. At MCAREC, harvest maturity occurred with 'Bartlett' to $19 \mathrm{~d}$ after 'Bartlett', depending on the year, with a mean of $8 \mathrm{~d}$ after 'Bartlett' (128 d after full bloom) (Table 2). Fruit firmness at this maturity was estimated to be $\approx 53.4 \mathrm{~N}(5 \mathrm{kgf})$ at MCAREC. Fruit maturity of 'Gem' at Clemson was estimated to be $27 \mathrm{~d}$ before 'Bartlett' with mean firmness of $58.8 \mathrm{~N}(6.0 \mathrm{kgf})$ and $75.5 \mathrm{~N}$ (7.7 kgf), respectively (Reighard et al., 2005).

Texture is moderately fine, similar to 'Bartlett' and 'Beurré Anjou'. Juiciness is moderate, also similar to 'Beurré Anjou'. At AFRS, fruit harvested from -2 to $+7 \mathrm{~d}$ in relation to 'Bartlett' and stored at $-1{ }^{\circ} \mathrm{C}$ air for up to 16 weeks and did not ripen when exposed to $20^{\circ} \mathrm{C}$ for $7 \mathrm{~d}$; fruit harvested 14 to $24 \mathrm{~d}$ after 'Bartlett' ripened normally to a soft, fine-grained, melting, juicy texture at $20^{\circ} \mathrm{C}$ after 11 weeks of cold storage; fruit harvested from 29 to $35 \mathrm{~d}$ after 'Bartlett' ripened after 6 weeks of cold storage. Fruit evaluated at harvest 14 to $35 \mathrm{~d}$ after Bartlett at AFRS and up to $36 \mathrm{~d}$ after 'Bartlett' at MCAREC 


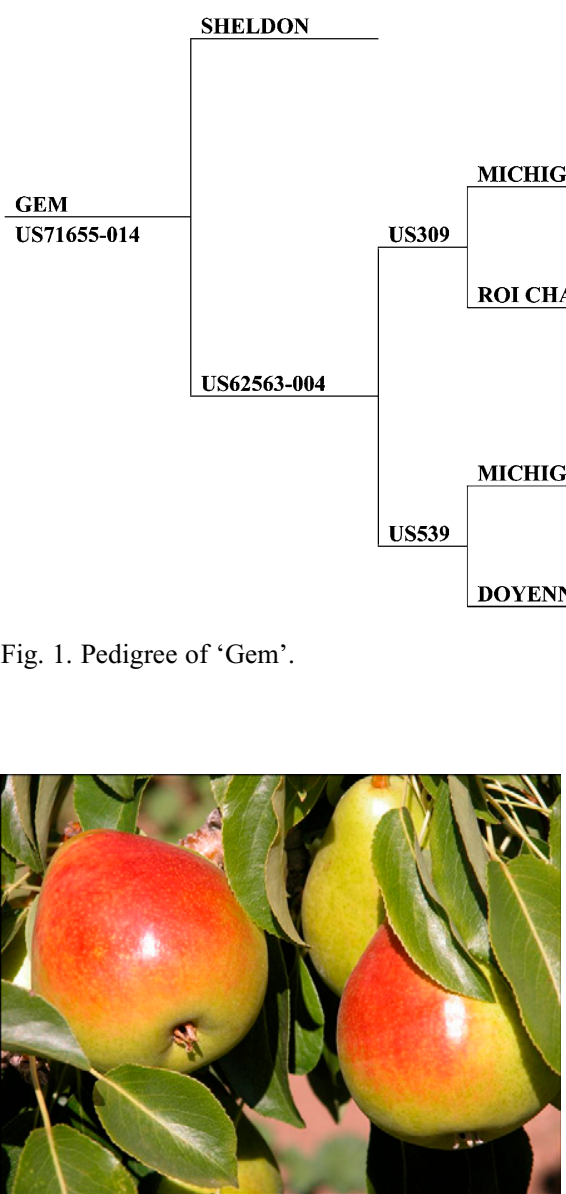

Fig. 2. Fruit of 'Gem'

was firm, crisp, and juicy. The fruit maintained its crisp, juicy texture when evaluated immediately on removal from cold storage for a period of up to 5 months. At MCAREC, when fruit was harvested at the earliest maturity ( $15 \mathrm{~d}$ after 'Bartlett' at a firmness of $53 \mathrm{~N}$ ), between 30 and $60 \mathrm{~d}$ of cold storage $\left(-1{ }^{\circ} \mathrm{C}\right.$ air) was necessary to ripen to a soft texture (Table 3); however, delaying harvest timing by 1 to 3 weeks shortened the chill requirement to less than $30 \mathrm{~d}$ (Table 3 ). Fruit were capable of storage up to 5 months in regular air without loss of ripening capacity at Hood River. Internal breakdown and premature ripening have not been observed. Flavor is mildly sweet with a light aroma, intermediate between 'Bartlett' and 'Beurré Anjou'. In 1-year trials at Gerbers, Fremont, MI, the Brix, acidity, texture, and consistency of 'Gem' were considered promising for baby food use. The only concern was a slight graygreen cast to the processed puree.

Productivity. 'Gem' is precocious and productive. At AFRS, first flowering occurred in the third leaf after planting of trees on 'Bartlett' seedling rootstock. At MCAREC, where the trees were on 'Old Home' $x$ 'Farmingdale' 97 rootstock, first flowering occurred in the second leaf with 30 clusters per tree, 1 year earlier than with 'Beurré Anjou'. Initial fruit set in the second leaf was over $50 \%$ and final yield was $\approx 2.5 \mathrm{~kg}$ per tree. Yields during the first 5 years were markedly and consistently greater than 'Beurré Anjou' (Table 4). Cumulative fruit set, yield per tree, and fruit number were significantly greater than 'Beurré Anjou'. However, in the unthinned condition, fruit size was significantly smaller (i.e., at the earliest September harvest date) than 'Beurré Anjou' (Table 4). Fruit size decreased over the 5 years as fruit yield increased. Yield efficiency of 'Gem' was 10 times greater than 'Beurré Anjou', whereas trunk cross-sectional area was significantly smaller. In subsequent experiments, delayed harvest or thinning resulted in an increase in fruit size (data not presented). The significantly smaller tree size of 'Gem', reflected in the trunk cross-sectional area (Table 4), indicated that the planting density of 839 trees/ha could be increased, resulting in a substantial increase in yield per hectare.

Bloom. Full bloom occurred approximately with 'Bartlett' (Table 2 ) and $\approx 4$ d after 'Beurré Anjou'.

Disease and insect resistance. 'Gem' was observed at AFRS to be moderately susceptible to epiphytotic fire blight with a mean score of 4.5 (van der Zwet et al., 1970), but significantly less susceptible than 'Bartlett' with a mean score of 2.5 (Table 5). No natural infection was observed at SWMREC or NWMHRC during a period of 8 years, including an epidemic year during 2000 at SWMREC when adjacent 'Bartlett', 'Bosc', and 'Anjou' trees were heavily blighted. Response to artificial inoculation of actively growing shoots, however, indicated a high level of resistance in shoots. Fewer shoots became infected, and the amount of necrosis, as indicated by both lesion length and percent lesion length, was significantly less for 'Gem'. Lesion length for 'Gem' was 15\% of that for 'Bartlett'. The more susceptible response resulting from natural infection may be the result of susceptibility to blossom infection and subsequent lesion development in the subtending older branches.

Data collected at the Mount Vernon Northwestern Washington Research and Extension Center of Washington State Univer-
Table 1. Mean fruit quality scores of 'Gem', 'Bartlett', and 'Beurré Anjou'.

\begin{tabular}{|c|c|c|c|}
\hline Trait & Gem & Bartlett & $\begin{array}{l}\text { Beurré } \\
\text { Anjou }\end{array}$ \\
\hline$\overline{\text { Length (mm) }}$ & $76.5 \mathrm{a}^{\mathrm{y}}$ & $79.6 \mathrm{a}$ & $74.5 \mathrm{a}$ \\
\hline Width (mm) & $70.9 \mathrm{a}$ & $66.9 \mathrm{a}$ & $70.8 \mathrm{a}$ \\
\hline $\begin{array}{l}\text { Stem length } \\
(\mathrm{mm})\end{array}$ & $29.2 \mathrm{a}$ & $28.2 \mathrm{a}$ & $13.3 \mathrm{~b}$ \\
\hline $\begin{array}{l}\text { Stem diameter } \\
\quad(\mathrm{mm})\end{array}$ & $3.4 \mathrm{a}$ & $3.1 \mathrm{a}$ & - \\
\hline Core $(\mathrm{mm})$ & $15.9 \mathrm{~b}$ & $20.3 \mathrm{a}$ & $21.0 \mathrm{a}$ \\
\hline Blush (\%) & $18.8 \mathrm{a}$ & $20.0 \mathrm{a}$ & $11.7 \mathrm{a}$ \\
\hline Russet $^{x}$ & $7.3 \mathrm{a}$ & $6.9 \mathrm{a}$ & $7.3 \mathrm{a}$ \\
\hline Appearance ${ }^{x}$ & $6.7 \mathrm{a}$ & $6.9 \mathrm{a}$ & $6.5 \mathrm{a}$ \\
\hline Texture $^{\mathrm{x}}$ & $6.1 \mathrm{a}$ & $6.3 \mathrm{a}$ & 6.4 \\
\hline Juiciness $^{\mathrm{x}}$ & $5.6 \mathrm{a}$ & $6.1 \mathrm{a}$ & 5.8 \\
\hline Grit $^{x}$ & $7.4 \mathrm{a}$ & $6.7 \mathrm{~b}$ & $6.5 \mathrm{~b}$ \\
\hline Flavor & $5.6 \mathrm{a}$ & $6.1 \mathrm{a}$ & $5.9 \mathrm{a}$ \\
\hline Aroma $^{\mathrm{v}}$ & $1.2 \mathrm{ab}$ & $1.8 \mathrm{a}$ & $1.0 \mathrm{~b}$ \\
\hline Scald $^{u}$ & $0.00 \mathrm{~b}$ & $0.03 \mathrm{~b}$ & 0.5 \\
\hline Storage life & 34 & 12 & 11 \\
\hline
\end{tabular}

(weeks) $^{t}$

${ }^{\mathrm{z}}$ All data except for 'Gem' storage life were collected from trees at the Appalachian Fruit Research Station. Fruit was stored at $-1{ }^{\circ} \mathrm{C}$ for variable lengths of time in perforated polyethylene bags. Means are based on yearly means of variable numbers of samples. Some samples harvested on the same harvest date were stored multiple storage times (1, 2, 3, and 4 months). For 'Gem', the means are based on a mean of 3.8 samples over 6 years. For 'Bartlett', the means are based on a mean of 2.7 samples over 15 years. For 'Beurré Anjou', the means are based on a mean of 2.0 samples per year over 5 years.

${ }^{y}$ Means followed by a different letter within rows are significantly different at the $P=0.05$ level, as determined by the $F$-test performed by SAS PROC GLM (SAS Institute, Cary, NC).

${ }^{x}$ Evaluation scale: $1=$ very poor to $9=$ excellent. Mean scores are for ripened and crisp fruit combined. Fruit evaluations were performed 5 to $7 \mathrm{~d}$ after removal from cold storage.

wFlavor evaluation scale: 1 = very poor (astringent or bitter) to $9=$ excellent (balance of sweetness and acidity. Score of $5=$ mildly sweet; score of $6=$ slight acidity. Fruit evaluations were performed 5 to $7 \mathrm{~d}$ after removal from cold storage.

${ }^{v}$ Aroma scale: $0=$ no aroma to $3=$ intense aroma. "Superficial scald scale: $0=$ no scald to $3=$ greater than $50 \%$ scalded skin.

'Minimum storage life without internal breakdown or scald. Data for 'Gem' based on storage trials at Oregon State University, Mid-Columbia Agricultural Research and Extension Center, Hood River, OR.

sity indicated that 'Gem' is susceptible to powdery mildew [Podosphaera leucotricha (Ellis \& Everh.) E. S. Salmon] with mean and maximum percentages of leaves infected of $2.5 \%$ and $30 \%$, respectively, and to pear scab (Venturia pirina Aderh.), with a mean infection of $3.33 \%$ of leaves and a maximum of $10 \%$ of leaves. Observations at AFRS indicated that it is also susceptible to Fabraea leaf and fruit spot [Diplocarpon mespili (Sorauer) Sutton]. 'Gem' is also susceptible to pear psylla (Cacopsylla pyricola Förster).

Fruit of 'Gem' and 'Beurré Anjou' were evaluated using artificial inoculations for resistance to three common postharvest fruit rot diseases, gray mold [Botrytis cinerea (De Bary) Whetzel], blue mold (Penicillium expansum Link), and Mucor mold (Mucor piriformis Scop.). The incidence of infection 
Table 2. Full bloom and harvest dates of 'Gem' and 'Beurré Anjou' pear trees relative to 'Bartlett' in Hood River, OR, and harvest date of 'Gem' and 'Beurré Anjou' pear trees relative to 'Bartlett' in Kearneysville, WV.

\begin{tabular}{|c|c|c|c|c|c|c|}
\hline \multirow[b]{2}{*}{ Cultivar } & \multicolumn{3}{|c|}{ Bloom (days) ${ }^{z}$} & \multicolumn{3}{|c|}{ Harvest (days) ${ }^{y}$} \\
\hline & Earliest & Mean & Latest & Earliest & Mean & Latest \\
\hline \multicolumn{7}{|l|}{ Oregon } \\
\hline Gem & -3 & 0 & 1 & 0 & 8 & 19 \\
\hline Beurré Anjou & -7 & -4 & -2 & 14 & 21 & 26 \\
\hline \multicolumn{7}{|l|}{ West Virginia } \\
\hline Gem & - & - & - & 17 & 21 & 30 \\
\hline Beurré Anjou & - & - & - & 14 & 20 & 24 \\
\hline
\end{tabular}

${ }^{\mathrm{z}}$ Full bloom data were recorded annually 2001-12. Positive numbers signify day after and negative numbers signify day before 'Bartlett'. Mean 'Bartlett' and 'Beurré Anjou' full bloom dates for the period were 17 Apr. and 13 Apr., respectively.

${ }^{y}$ Harvest data were recorded annually 2001-12 at Hood River, OR. Mean harvest dates for that period were 15 Aug. and 5 Sept. for 'Bartlett' and 'Beurré Anjou', respectively. Mean firmness for 'Bartlett' and 'Beurré Anjou' were $82.3 \mathrm{~N}$ and $64.9 \mathrm{~N}$, respectively. At the Appalachian Fruit Research Station, harvest data were recorded from 1989 to 1993. Mean 'Bartlett' and 'Beurré Anjou' harvest dates were 18 Aug. and 16 Sept., respectively.

Table 3. Effects of harvest date and cold storage duration on fruit firmness and the development of ripening capacity in 'Gem' pear."

\begin{tabular}{llcc}
\hline & & Firmness (N) & \\
\cline { 2 - 4 } Harvest date $^{\mathrm{y}}$ & Harvest & $30 \mathrm{~d} \mathrm{PH}$ & $60 \mathrm{~d} \mathrm{PH}^{\mathrm{x}}$ \\
\hline $15 \mathrm{~d}$ & $53.3 \mathrm{a}^{\mathrm{w}}$ & $23.0 \mathrm{a}$ & $10.8 \mathrm{a}^{\mathrm{v}}$ \\
$21 \mathrm{~d}$ & $48.1 \mathrm{~b}$ & $11.7 \mathrm{~b}$ & $10.4 \mathrm{a}$ \\
$29 \mathrm{~d}$ & $46.4 \mathrm{bc}$ & $6.1 \mathrm{c}$ & $8.2 \mathrm{a}$ \\
$36 \mathrm{~d}$ & $42.9 \mathrm{c}$ & $5.2 \mathrm{c}$ & $7.4 \mathrm{a}$ \\
\hline
\end{tabular}

${ }^{2}$ Data are means of four replicates $(\mathrm{n}=20)$.

'Days after 'Bartlett' harvest. 'Bartlett' were harvested on 29 Aug.

${ }^{x}$ Postharvest $(\mathrm{PH})$ storage of 30 or $60 \mathrm{~d}$ at $-1{ }^{\circ} \mathrm{C}$ in regular air plus a $7-\mathrm{d}$ ripening period at $20^{\circ} \mathrm{C}$.

${ }^{\text {w} M e a n s ~ w i t h i n ~ c o l u m n s ~ w e r e ~ s i g n i f i c a n t l y ~ d i f f e r e n t ~ b y ~ l e a s t ~ s i g n i f i c a n t ~ d i f f e r e n c e ~ a t ~} P<0.05$.

${ }^{v}$ Softening of $13 \mathrm{~N}$ or less after ripening implies that ripening competency was achieved.

Table 4. Cumulative performance data over a 5 -year cultivar trial in Hood River, OR. ${ }^{z}$

\begin{tabular}{lcccccr}
\hline Cultivar & $\begin{array}{c}\text { Fruit set (fruit/ } \\
100 \text { clusters })\end{array}$ & $\begin{array}{c}\text { Yield } \\
(\mathrm{kg} / \text { tree })\end{array}$ & $\begin{array}{c}\text { Fruit no. } \\
(\text { no./tree })\end{array}$ & $\begin{array}{c}\text { Mean fruit } \\
\mathrm{wt}(\mathrm{g})\end{array}$ & $\begin{array}{c}\mathrm{TCSA}^{\mathrm{y}} \\
\left(\mathrm{cm}^{2}\right)\end{array}$ & $\begin{array}{r}\mathrm{YE}^{\mathrm{x}} \\
\left(\mathrm{kg} \cdot \mathrm{cm}^{-2}\right)\end{array}$ \\
\hline Gem & $87.7 \mathrm{a}^{\mathrm{w}}$ & $45.0 \mathrm{a}$ & $302 \mathrm{a}$ & $150 \mathrm{~b}$ & $37.8 \mathrm{~b}$ & $1.21 \mathrm{a}$ \\
Beurré & $20.6 \mathrm{~b}$ & $6.4 \mathrm{~b}$ & $35 \mathrm{~b}$ & $182 \mathrm{a}$ & $52.9 \mathrm{a}$ & $0.12 \mathrm{~b}$ \\
$P>\mathrm{F}$ & $<0.0001$ & $<0.0001$ & $<0.0001$ & 0.0062 & $<0.0001$ & $<0.0001$ \\
\hline
\end{tabular}

${ }^{\mathrm{z}}$ Cultivars were grafted onto $\mathrm{OH} \times \mathrm{F} 87$ rootstock and trained to a central leader. The planting was established in 2005 at a density of 839 trees/ha $(2.5 \mathrm{~m} \times 4.8 \mathrm{~m})$.

${ }^{\mathrm{y}} \mathrm{TCSA}=$ trunk cross-sectional area measured $20 \mathrm{~cm}$ above the graft union in 2009.

${ }^{\mathrm{x}} \mathrm{YE}=$ yield efficiency, computed as kilograms of fruit per $\mathrm{cm}^{2}$ or TCSA.

${ }^{w}$ Means within columns with different letters are significantly different by least significant difference at $P=0.05$.

varied from $84 \%$ for Mucor mold on 'Beurré Anjou' to $100 \%$ for blue mold on 'Beurré Anjou' (data not presented), but there were no significant differences between the cultivars. Mean lesion diameters ranged from 25.2 $\mathrm{mm}$ for Botrytis on 'Beurré Anjou' to $51.4 \mathrm{~mm}$ for Mucor on 'Gem'. Although mean lesion diameter for Botrytis was greater on 'Gem' than on 'Beurré Anjou' in 2004, there were no significant differences between cultivars for any of the three pathogens when data from both years were analyzed (data not presented).
Table 5. Fire blight reaction to natural and artificial infection of 'Gem' and 'Bartlett'.

\begin{tabular}{|c|c|c|c|c|}
\hline \multirow[b]{2}{*}{ Variable } & \multicolumn{2}{|c|}{ Bartlett } & \multicolumn{2}{|c|}{ Gem } \\
\hline & No. $^{z}$ & Mean & No. $^{z}$ & Mean \\
\hline Epiphytotic & & & & \\
\hline USDA score ${ }^{y}$ & 36 & $2.5 \mathrm{~b}^{\mathrm{x}}$ & 4 & $4.5 \mathrm{a}$ \\
\hline Artificial inoculation ${ }^{\mathrm{w}}$ & & & & \\
\hline $\begin{array}{l}\text { Percent infected } \\
\text { shoots }\end{array}$ & 20 & $60 \mathrm{a}$ & 20 & $25 \mathrm{~b}$ \\
\hline Shoot length $(\mathrm{mm})$ & 12 & $382 \mathrm{~b}$ & 5 & $580 \mathrm{a}$ \\
\hline Lesion length $(\mathrm{mm})$ & 12 & $311 \mathrm{a}$ & 5 & $48 \mathrm{~b}$ \\
\hline $\begin{array}{l}\text { Percent lesion } \\
\text { length }^{\mathrm{v}}\end{array}$ & 12 & $83 \mathrm{a}$ & 5 & $8 \mathrm{~b}$ \\
\hline
\end{tabular}

${ }^{\mathrm{z}}$ Sample sizes: for epiphytotic (natural infection) scores, no. refers to the number of trees observed over a 10-year period. 'Bartlett' trees consisted of four sets planted in 1982, 1983, 1984, and 1986. 'Gem' trees were planted in 1984. For artificial inoculation, no. refers to the number of shoots. Data on shoot length, lesion length, and percent lesion length are for infected shoots only.

'Lowest (most severe) USDA fire blight score (van der Zwet et al., 1970) over a period of 10 years, in which $1=$ dead and $10=$ no infection.

${ }^{\mathrm{x}}$ Means followed by a different letter within rows are significantly different at the $P=0.05$ level. Significance of differences for epiphytotic scores, shoot length, lesion length, and percent lesion length were determined by F-test, performed using SAS PROC GLM (SAS Institute, Cary, NC) Significance of differences in percent infected shoots was determined by $\chi^{2}$ test performed using SAS PROC FREQ.

wTwenty actively growing shoots on single orchardgrown trees of each cultivar were inoculated using a hypodermic syringe with a $10^{8}$ colony-forming units $/ \mathrm{mL}$ suspension of isolate AFRS 581 of Erwinia amylovora. The data presented were recorded 8 weeks post-inoculation when infection had ceased. ${ }^{v}$ Percent lesion length calculated by dividing lesion length by shoot length.

Plant Germplasm System, where it will be available for research purposes, including development and commercialization of new cultivars. It is requested that appropriate recognition be made if this germplasm contributes to the development of a new breeding line or cultivar.

\section{Literature Cited}

Budwood of 'Gem' is limited and trees are not available from the U.S. Department of Agriculture, Oregon State University, Michigan State University, or Washington State University. Interested nurseries and researchers should send requests for noncertified budwood to Richard L. Bell. Pathogen-free certified budwood will be available from the National Clean Plant Network-Fruit Trees in Prosser, WA. Genetic material of this release will be deposited in the National
Reighard, G.L., D.R. Ouellette, and K.H. Brock. 2005. Field performance of fire blight tolerant Pyrus communis selections in South Carolina. Acta Hort. 671:213-218.

Thibault, B., R. Watkins, and R.A. Smith (eds.) 1983. Descriptor list for pears (Pyrus). Intl. Board Plant Genet. Resources, Rome, Italy.

van der Zwet, T., W.A. Oitto, and H.J. Brooks. 1970. Scoring system for rating the severity of fire blight in pear. Plant Dis. Rptr. 54:835-839.

Zielinski, Q.B. 1955. Modern systematic pomology. W.C. Brown, Dubuque, IA. 